\title{
Uuden aallon voimalla
}

\author{
Elämänkulkuanalyysi Lepakkoluolan \\ nuorisokulttuuristen toimijoiden työurien \\ muotoutumisesta omaehtoisiksi uriksi
}

Niin sanotun nuorisokulttuurin parissa toimii 2020-luvulla henkilöitä, jotka ovat ylittäneet kansaneläkkeeseen oikeuttavan ikärajan. Viime vuosikymmenellä akateeminen tutkimus on kiinnostunut nuorisokulttuurin ikääntyvistä osallistujista (esim. Hodkinson 2016; Bennett 2013). Samalla on osoitettu, että nuoruuden kulttuuriset käytännöt voivat vaikuttaa elämänkulun muotoutumiseen, esimerkiksi työpaikan valintaan (esim. Haenfler 2018). Joillekin nuorisokulttuurin tuottaminen edustaa houkuttelevaa uravaihtoehtoa (Bennett 2013: 94-122), joka eroaa yhteiskunnan odottamista koulun penkiltä palkkatyöhön johtavista siirtymäpoluista ja jolle skeneissä kerrytetyt tiedot ja taidot luovat pohjan (Bennett 2018; Threadgold 2015). Tässä tutkimuksessa tarkastelen nuorisokulttuurisen toiminnan muuttumista elämänmittaiseksi työuraksi. Tutkin elämänkulkuanalyysin tulkintakehyksessä (esim. Kok 2007), miten Helsingin Ruoholahdessa vuosina 1979-1999 toimineen kulttuuritila Lepakkoluolan eli Lepakon varhaisen (1979-1985) musiikkiskenen viisi toimijaa ovat luoneet epämuodollisesta ja instituutioiden ulkopuolisesta toiminnasta itselleen uran musiikin ja nuoriso- ja kaupunkikulttuurin tuotannossa. Tarkastelen, millaisessa suhteessa elämänkulkuanalyysin eri aksioomat (ajoittuminen, toimijuus, sosiaaliset suhteet, elämänkulun kertyvä luonne, historialliset rakenteet) ja ikään liitetyt sosiaaliset ja taloudelliset odotukset ovat suhteessa uran muotoutumiseen.

Esitän, että omaehtoiset urat (DIY (do it yourself) career, Bennett 2018) rakentuvat neljästä toisiaan seuraavasta, limittäisestä ja osin päällekkäisestä henkilön ikään sidotusta vaiheesta. Osoitan nuoruuden sosiokulttuurisen ympäristön ja yksilöllisten kulttuurimieltymysten voivan ohjata varhaisaikuisuuden (ks. Arnett 2014) työelämäsiirtymien valintoja (ks. myös Woodman \& Bennett 2015: 2). Tämän tutkimuksen haastateltavien nuoruuden kulttuurinen toimijuus on jatkunut läpi elämänkulun elämän valintoja ohjaavina merkityksenantoina, identiteetteinä ja ammattitaitona (vrt. Bennett 2018; Threadgold 2015). Vuorovaikutus skenessä vahvistaa yksilöiden nuorisokulttuurista toimijuutta ja ohjaa yksilöiden ajattelumalleja kohti omaehtoisen uran mahdollisuutta sekä kerryttää sen vaatimaa tietotaitoa. 
Onnistuneen, palkkatyöhön johtavan omaehtoisen työelämäsiirtymän taustalla ovat yksilön nuorisokulttuurisen toimijuuden ja historiallisen ajan ja paikan luomien mahdollisuuksien kohtaaminen - tässä tutkimuksessa pop-musiikin ja kaupunkikulttuurin suosion kasvu 1980- ja 1990-luvuilla (ks. esim. Mäenpää 2005; Ruoppila \& Cantell 2000). Kun toimijat varttuvat, erkaantuvat suorasta skene-osallisuudesta ja siirtyvät aikuisen rooliin, he sopeuttavat kulttuurisia ihanteitansa toimeentulon realiteetteihin esimerkiksi perustamalla yrityksiä. Yksilöiden vuosikymmeniä jatkuvan vaihtoehtoisen toiminnan seurauksena uudenlainen populaari- ja kaupunkikulttuuri vakiintuu yhteiskuntiin.

Tutkimukseni nivoutuu alakulttuuritutkimustraditioon ja löytää paikkansa nuorisotutkimuksen ja etnomusikologisen työuria koskevan tutkimuksen rajapinnoilta. Sosiologit Dan Woodman ja Andy Bennett (2015: 2) esittävät, että nuorisokulttuuri- ja siirtymätutkimuksen yhdistävä näkökulma tavoittaa työurapolun rakentumisen nykyistä siirtymätutkimusta kokonaisvaltaisemmin. Näkökulmat yhdistyvät kuitenkin jo Paul Willisin sosiologian klassikossa Learning to Labour (1977). Willis kuvaa, miten isobritannialaiset työväenluokkaiset koulupojat sosialisoituvat koulun vastaiseen ja ruumiillisia työpaikkoja arvostavaan alakulttuuriin. Toisen asteen koulutuksen jälkeen pojat siirtyvät vanhempiensa luokka-aseman mukaiseen suorittavaan työhön. (Willis 1977; ks. myös esim. MacDonald \& Schildrick 2007). Nuorisotutkijoiden Päivi Bergin ja Tiina Ylöstalon mukaan 40 prosentille nykynuorista $(\mathrm{n}=771)$ harrastus on vaikuttanut heidän ammatinvalintaansa, ja valinnassa arvot korostuvat toimeentulon kustannuksella: harrastuksesta ammatin tehneet arvostavat työssä enemmän itsensä toteuttamista, kavereiden kanssa toimimista, auttamista ja yhteiskuntaan vaikuttamista kuin rahaa (Berg \&Ylöstalo 2020: 183). Lepakkoluolan nuorisokulttuuriset toimijat voidaankin nähdä edelläkävijöinä 2000-luvulla yleistyneisiin keskusteluihin vapaa-ajan identiteetin toteuttamisesta työssä. Tämä tutkimus valottaa, mitä tapahtuu bändin hajoamisen jälkeen, kun tapahtumatuottaja saa lapsia tai nuorison perustama radiokanava myydään ylikansalliselle yhtiölle.

Vaikka viime vuosikymmenen aikana on julkaistu lukuisia musiikkialan ammattilaisiin ja puoliammattilaisiin keskittyviä tutkimuksia (esim. Haenfler 2018; Tarassi 2018; Threadgold 2018; 2015), ei musiikki- ja muuhun kulttuurituotantoon osallistumisen muuntamisesta työuriksi ole paljoa tutkimustietoa (ks. esim. Hesmondhalgh \& Baker 2011: 55-56). Tutkimustuloksien perusteella amatööriyden ja ammattilaisuuden rajapinnalla toimiminen tarkoittaa usein prekaariutta, yrittäjyyden eri muotoja, itseohjautuvuutta, itsensä markinointia ja itseriistoa (self-exploitation). Toimintaan liittyy usein myös taiteellisen työskentelyn yhteensovittamista muihin töihin. Toisaalta musiikin kanssa toimiminen koetaan merkitykselliseksi ja itsessään työstä saatavaksi palkkioksi. Osaa alan ammattilaisista motivoi pyrkimys tietoisesti parantaa musiikin (ja muun kulttuurin) asemaa yhteiskunnassa (esim. Jian 2018). 
Aiemmat tutkimukset musiikkialan työurista eivät kuitenkaan sisällä pitkittäisnäkökulmaa eivätkä siten ole saavuttaneet tutkimukseni keskeistä tavoitetta: omaehtoisen uran rakentumisen tarkastelua sen alusta loppuun.

\section{Lepakkoluola osana Helsingin nuoriso- ja kaupunkikulttuurin historiaa}

Helsingin nuoriso- ja kaupunkikulttuurin historian viimeisimmät 40 vuotta toimivat tutkimieni elämänkulkujen taustalakanana. Muutokset makrotason yhteiskunnallisissa rakenteissa ovat muovanneet käsittelemiäni omaehtoisia uria ja mahdollistaneet ne. Nykymuotoinen nuorisokulttuuri, joka yhdistää esteettiset ja kulutukselliset mieltymykset, kuten musiikkimaun ja tyylin, muotoutui elintason nousun myötä toisen maailmansodan jälkeisinä vuosikymmeninä angloamerikkalaisessa maailmassa. Samalla nuoret alkoivat tehdä itse pop-musiikkia ja luoda puitteita sen omaehtoiselle tuotannolle. (Bennett 2001: 135.) Vaikka nuorisokulttuuri rantautui myös Suomeen jo sodanjälkeisinä vuosikymmeninä, se tuli laajamittaisesti osaksi yhteiskuntaa vasta 1970-luvulla (Heiskanen \& Mitchell 1985: 111-113, 178-180, 204-206; ks. myös Mäenpää 2005). Yhdessä nuorisokulttuurin nousun kanssa rock-musiikki sai sijaa (Kurkela 2003: 514). Suomalaista rock-kenttää vavisutti 1980-luvun taitteen molemmin puolin punk-innostuksen vanavedessä syntynyt "uusi aalto", johon kuului omaehtoinen poliittinen ja yhteiskunnallinen liikehdintä. Liikehdintää edustaa muun muassa Koijärvi-liike (ks. esim. Sommar 2013).

Uuden aallon yhteiskunnallisessa tyrskynnässä nuorisojoukko valtasi Lepakkoluolan elokuussa 1979. Tyhjä ja huonokuntoinen entinen vernissa- ja maalitehtaan varasto oli toiminut ennen valtausta asunnottomien yösijana. Ennen kaikkea Elävän musiikin yhdistys ELMU ry:n (myöhemmin tekstissä Elmu) aktiivit kunnostivat tilan musiikki- ja muuta kulttuurikäyttöä varten. (Rantanen 2000; Bruun ym. 1998: 273.) Lepakolla on ollut Helsingissä erityinen merkitys erikoistuneiden eli valtavirrasta poikkeavien pop-musiikin muotojen edistäjänä. 1980-luvun alussa tällaisia olivat hardcore-punk, post-punk ja neo-rockabilly (Rantanen 2000: 160-161). Vuonna 1985 tilaan perustettiin Suomen historian toinen kaupallinen radiokanava. Radio City oli Elmun ja Yleisradiosta lähteneiden nuorten toimittajien yhteisponnistus, joka soitti pop-musiikkia aikana, jolloin se muuten kuului vain harvoin ääniaalloilla (Kemppainen 2015: 173-175). Lepakossa nuoret opettelivat lukuisia taitoja, kerryttivät tietoja ja tutustuivat muihin nuorisokulttuurin toimijoihin. Myöhemmin jotkut heistä muodostivat toiminnastaan elämänmittaisia urapolkuja media- ja kulttuurialan ammattilaisina, taiteilijoina ja muusikkoina, ja jopa viittaavat nuoruusvuosiinsa "Lepakon korkeakouluna". (Helistö 2018: 53-56.) 
Rock-musiikin varsinainen valtavirtaistuminen ja "suomirockin" muotoutuminen tapahtuivat 1980-luvun loppuun mennessä (Skaniakos 2021; Muikku 2001: 251257). Vuosikymmenen lopulla Elmu houkutteli nuorempia osallistujia Lepakkoon hiphop- ja heavy metal -alakulttuuritapahtumilla ja 1990-luvulla myös elektronisella tanssimusiikilla (Mäenpää 2005: 11; Rantanen 2000). Helsingin katukuvaan hiphopin ja tanssimusiikin tapahtumat ja erikoisliikkeet ilmestyivät 1990-luvun alkupuolella (Seppälä \& Hellman 2014: 333; Westinen 2014: 39). Jälkimodernista kaupunkikulttuurista tuli Helsingissä arkipäivää 1990-luvun aikana. Kaupunkikulttuurin läpimurrolle keskeistä oli juuri pop-musiikki, uusi kaupunkimedia kuten City- ja Image-lehdet, Radio City ja toisaalta nuorison rooli muutoksen edistäjänä. Helsingin ydinkeskustan rooli korostui vapaa-ajanvieton ja kulttuurin, mutta myös yöelämän keskuksena. (Mäenpää 2005: 11-20, 353-357; ks. myös Ruoppila \& Cantell 2000: 37-38.) Muutos näkyy tämän tutkimuksen haastateltavien elämänkuluissa, kun he irtautuvat Lepakosta toimimaan muille kaupungin yöelämän ja kaupunkikulttuurin näyttämöille.

\section{Skene, omaehtoinen ura ja elämänkulkuanalyysi}

Skenen käsitteen pioneeri musiikintutkija Will Straw (1991) näkee musiikillisten toimien tapahtuvan rinnakkaisissa ja vuorovaikutteisissa verkostoissa. Käsitteellä on erilaisia käyttötapoja (ks. Straw 2015), joista sitoudun paikalliseen skeneen. Paikalliset musiikkiskenet ovat musiikillisten toimien ympärille rakentuneita limittäisiä verkostoja, jotka toimivat tietyssä maantieteellisesti rajatussa infrastruktuurissa (Bennett 2004: 226-231). J. Patrick Williamsin (2011) tavoin näen nuorisokulttuurin muodostuvan sosiofyysisen skenen lisäksi sitä täydentävästä kulttuurisesta sisällöstä, alakulttuureista. Alakulttuuri muodostuu tietyistä materiaalisista (esim. pukeutumistyyli) ja immateriaalisista (esim. puhetapa) elementeistä, joihin käyttäjät liittävät tiettyjä jaettuja arvoja ja uskomuksia. (Williams 2011: 39-40; Thornton 1995; ks. myös Hänninen 2021.) Eri osallistujat sitoutuvat ja satsaavat eri asteisesti alakulttuureihin (vrt. Lähteenmaa 2000: 71-74). Jotkut yksinkertaisesti osallistuvat skeneen, kun toisista tulee sen keskeisiä toimijoita. Kiinnittymisen aste vaihtelee elämänkulun mittaan, kun osallistujan roolit skenessä muuttuvat. Alastair Gordonin (2014) mukaan skene-osallistumisen tasoja ovat periferia, semiperiferia ja ydin, joilla edetessään osallistuja tutustuu skeneen ja alkaa toimia sen parissa.Ydintason toimija on skeneä ja alakulttuuria tuottavassa (reproduce) roolissa. Eri osallistuja- ja toimijaroolit ovat statushierarkiassa, jossa asema määrittyy bourdieulaisen pääomateorian hengessä heidän alakulttuurisen pääomansa mukaisesti. Alakulttuurinen pääoma on kulttuurista tietoisuutta, jota voidaan osoittaa objektivoituna (objectified, esim. laaja levykokoelma) tai ruumiillistettuna (embodied, esim. puhetyyli) (Thornton 1995: 11-14). 
Alakulttuurit ja skenet ovat olemassa ja toteutuvat skene-osallistujien arjen toistuvissa teoissa, puheessa ja rituaaleissa (esim. Glass 2012). Sosiaalisen konstruoinnin lisäksi skene-toimijat tuottavat skeneä myös konkreettisilla ponnistuksilla esimerkiksi järjestämällä erikoistuneiden pop-musiikin genrejen tapahtumia. Bennett (2018) on määritellyt skenen tuottamisesta juontuvat työurat käsitteellä $D I Y$ (do it yourself) career. Olen suomentanut sen muotoon omaehtoinen ura, koska näen sen "itsetehtyjä" tai "tee se itse -uria" (ks. esim. Berg \&Ylöstalo 2020: 179) osuvampana tavoittamaan ruohonjuuritason kulttuuri- ja musiikkitoiminnasta kumpuavat urapolut. Käsite liittyy 2000-luvulla kasvaneeseen akateemiseen kiinnostukseen nuorisokulttuurin ikääntyvistä osallistujista, mikä on haastanut ajatuksen siitä, että nuorisokulttuureihin osallistuminen on väliaikainen ja ohimenevä vaihe (ks. Bennett 2013: 18-20; suomalaistutkimuksessa esim. Vuori 1971: 110). Alan tutkimus on myös huomioinut, että nuorisokulttuuriin osallistuminen voi ohjata elämänkulun muotoutumista ja heijastua aikuisena arvoissa, elämänvalinnoissa ja tyyleissä (Haenfler 2018; Peipinen 2018; Hodkinson 2016; Bennett 2013). Toisaalta yksilön sosiaalisen ja psykologisen ikääntymisen on huomattu myös heijastuvan tarpeena sopeuttaa omaa nuorisokulttuurista osallisuutta täysi-ikäisiltä odotettuun taloudelliseen itsenäisyyteen (Davis 2012) ja sosiaalisesti "kunnollisen", yhteiskunnan hyväksymän ja arvostaman, aikuisen rooliin (Bennett 2013).

Tutkimukseni metodologisteoreettisena taustana toimii elämänkulkuanalyysi. Menetelmällä tavoitetaan ihmiselämän kulku ja elämän eri osa-alueiden rooli yksityiskohtaisesti. Metodi tunnistaa viisi ihmiselämän aksioomaa, jotka ovat vastavuoroisessa riippuvuussuhteessa ja yhdessä vaikuttavat elämän muotoutumiseen. Aksioomat ovat: 1) historiallinen aika ja paikka, 2) sosiaaliset suhteet tai "linkittyneet elämät", 3) siirtymät ja niiden ajoitus, 4) elämänkulun kertyvä tai "kumuloituva" luonne ja 5) toimijuus. Metodin taustalla on oletus elämänkulusta holistisena kokonaisuutena, jossa risteytyy aksioomien, yksilöllisen iän ja yhteiskunnallisen ajan vaikutus. Yhdessä nämä tekijät ratkaisevat elämänkulun lopputuloksen. (Häkkinen 2012; Kok 2007.) Historiallisen ajan ja paikan aksiooma on elämänkulkujen makrotaso eli yhteiskunnan rakenteet: kaikki ihmiset syntyvät kohorttiin, joka kohtaa tietyt yhteiskunnalliset olosuhteet ja muutokset. Rakenteet luovat elämänkulun aikana sekä mahdollisuuksia että rajoituksia. (Kok 2007: 205). Tämän tutkimuksen elämänkulkujen historiallinen konteksti on Helsinki 1960-luvulta nykypäivään.

Mikrotason aksioomista toinen, linkittyneet elämät, viittaa elämänkulkujen välisiin vuorovaikutteisiin sosiaalisiin suhteisiin. Metodologinen kirjallisuus korostaa etenkin perheen vaikutusta (Kok 2007: 205), mutta nuorille ikätovereiden vaikutus on myös erityisen painoarvoinen (esim. Gecas 2003). Siirtymät viittaavat elämänkulun muodostaviin erilaisiin roolimuutoksiin. Esimerkiksi yliopiston keskeyttäminen ja 
bändin suosion myötä syntynyt julkisuus ovat siirtymiä. Sarjana esiintyvät ja toisiinsa liittyvät siirtymät muodostavat polkuja (trajectory). Esimerkiksi koulutuspolku ja musiikkiharrastuspolku ovat yksilön elämänkulkua muodostavia polkuja. Siirtymät ajoittuvat yleensä normatiivisesti elämänkulussa, jolloin tietyn ikäisten ihmisten odotetaan läpikäyneen tiettyjä siirtymiä, ja väärin ajoittuvista siirtymistä voidaan sanktioida sosiaalisesti. Sosiaalinen ikääntyminen on siis elämänkulun taustaoletus, joka ohjaa yksilöä kohti tietynlaisia elämäntapahtumia, mutta myös tietynlaista käyttäytymistä. Esimerkiksi useat koulutukseen ja ansiotyöhön liittyvät siirtymät ovat tällaisia ikänormatiivisia siirtymiä (ks. esim. Kohli 2007). Elämänkulku on kumuloituva, eli esimerkiksi yksilö tekee valintoja kertyneen maailmankuvansa mukaisesti tai kerryttää tietynlaista ammattitaitoa. (Häkkinen 2012; Kok 2007: 204-205.)

Toimijuudellaan ihmiset kykenevät ylittämään historiallisten rakenteiden vaikutuksen ja ohjaamaan elämänkulkuaan vasten aikakauden yleisiä kehityskulkuja sekä muovaamaan yhteiskuntaa (Elder Jr. 1994; ks. myös Giddens 1984). Yksilöllinen toimijuus ja sen suunta rakentuvat erilaisista tekijöistä. Epifaniat eli valaistumiskokemukset - psykologiset itseymmärryksen hetket, joissa elämänkulun halut ja pyrkimykset kirkastuvat (Denzin 2001: 37) - ohjaavat toimijuuden suuntaa. Näihin kuuluvat myös musiikilliset epifaniat eli musiikkimuistoihin liitetyt, elämän mullistaneiksi koetut hetket (Green 2016). Toimijuutta ruokkivat yksilöpsykologiset identiteettiin kietoutuvat ominaisuudet kuten sukupuoli tai etnisyys, sosiaaliset tekijät kuten perhe ja kaverit sekä koulun ja työpaikan kaltaisissa sosiaalisissa instituutioissa menestyminen (Gecas 2003), mutta myös yksilöllisten ja yhteiskunnallisten olosuhteiden kyky- ja odotushorisontti (Hitlin \& Johnson 2015).

\section{Metodologia ja aineisto}

Tutkimukseni aineisto muodostuu viidestä puolistrukturoidusta temaattisesta elämäntarinahaastattelusta. Elämäntarinahaastattelussa haastateltava kertoo elämästään omin sanoin ja valikoiden, mitä haluaa paljastaa ja painottaa (Atkinson 1998). Toteutin haastattelut elo- ja syyskuussa 2018, äänitin ne digitaalisesti ja litteroin kokonaisuudessaan. Haastattelut kestävät kahdesta neljään tuntia. Haastateltavat ovat 1950-1962 syntyneitä miehiä. Heidät on valittu ennalta tiedossa olleen omaehtoisen uran ja Lepakkoluolan skeneen vuosina 1979-1985 osallistumisen perusteella. Tuona aikana Lepakko vallattiin ja kunnostettiin, ja se toimi omaehtoisen kulttuurin näyttämönä ja harjoittelupaikkana. Haastateltavat ovat Christian Moustgaard (s. 1950), Teemu Lehto (s. 1957), Kimmo Helistö (s. 1961), Jyrki "Njassa” Jantunen (s. 1962) sekä Pasi "Panda" Nikander (s. 1962). Christian oli perustamassa Elmua ja Lepakkoluolaa ja toimi Radio Cityn toimitusjohtajana, kaapelikanava ATV:n perustajana ja kaupunkilehti Nöjesguiden Suomen osastonjohtajana. Teemu oli valtaamassa 
Lepakkoluolaa ja toimii nykyisin työtilayhteisö Tilajakamossa sekä IT-alalla. Kimmo soitti Kadotetut-yhtyeessä, toimi Radio Cityn juontajana, Elmun puheenjohtajana sekä Helsingin kunnanvaltuutettuna; hän isännöi nykyisin saunoja Arlan Sauna ja Uusi Sauna. Jyrki lauloi Musta Paraati -yhtyeessä ja toimi Radio Cityn juontajana, ja työskentelee nykyään Radio Helsingissä. Pasi soitti Musta Paraati -yhtyeessä ja on työskennellyt Lepakossa, Elmussa, tapahtumatuottajana sekä käytetyn audiotekniikan myyjänä. Haastatteluaineistoa on käsitelty tieteen eettisten periaatteiden mukaisesti (TENK 2019). Haastateltaviin oltiin uudelleen yhteydessä ennen artikkelin julkaisua ja lupa heidän nimiensä käyttöön tutkimuksessa varmistettiin. ${ }^{1}$

Käsittelen haastatteluaineistoa muistitietona, jota käytetään erityisesti mikrohistoriassa tavoittamaan huonosti tunnettuja ilmiöitä. Mikrohistoriallisen katsantokannan tavoitteena on tehdä päätelmiä yhteiskunnan makrotasosta mikrotason kautta. (Fingerroos \& Haanpää 2006: 30-34; Peltonen 2001). Tässä tutkimuksessa haastateltavien elämänkulut valottavat siis myös laajempia yhteiskunnallisia muutoksia, jotka näkyvät pop- ja kaupunkikulttuurin kasvaneessa suosiossa viimeisimpien 40 vuoden aikana.

Tutkimus vaatii aina tutkijalta refleksiivistä paikantamista niin epistemologismetodologisesti kuin tutkijan subjektiivisten ja yhteiskunnallisten sitoumusten osalta (Fingerroos 2003). Epistemologialtaan elämäntarina on pohjimmiltaan haastateltavan ja haastattelijan luoma konstruktio, mutta haastattelujen nähdään paljastavan elämänkulun tapahtumia (kuten koulutuksen päättyminen, siirtymä työelämään tai musiikintuottamisen aloittaminen) sekä subjektiivisia kokemuksia ja merkityksenantoja (Abrams 2016; Fingerroos \& Haanpää 2006: 36-40). Tutkimusta tehdessä pyrin välttämään tiedostamattomien ennakkokäsitysten tunkeutumisen tutkimusasetelmaan. Aineistoa kerätessä välttelin haastattelujen kulun ohjaamista. Aloitin pyynnöllä "kerro elämäkertasi nuorisokulttuurin näkökulmasta", jonka jälkeen esitin laaja-alaisesti erilaisia avoimia kysymyksiä (ks. Hänninen 2019: 122-123), joiden tarkoituksena oli kattaa tutkimusaihe moninäkökulmaisesti. Tarkentavia kysymyksiä esitin vain, kun se oli välttämätöntä keskustelun jatkumiseksi. Lähtökohtaisesti roolini oli kuunnella, kun haastateltava kertoi vapaasti keskusteltavasta teemasta ja siitä mieleen juolahtaneista aiheista.

1 Christian Moustgaardiin ei ole voitu olla yhteydessä hänen menehdyttyään marraskuussa 2018. Haastattelussa hän oli myötämielinen haastattelun käytölle nimellään ja antoi myös suullisen luvan arkistoida haastattelu nimellään. Christianin elämänvaiheet, joita artikkeli käsittelee, ovat kaikki mediasta löydettävissä, ja hän on puhunut osallistumisestaan nuorisokulttuuriin laajasti esimerkiksi teoksissa Nupit kaakkoon! (Lindfors ym. 1988) ja Miksei aina voi olla perjantai? (Värri 2018). Näiden seikkojen valossa kirjoitan hyvällä omallatunnolla Christianista hänen nimellään artikkelissa. 
Tunnen suomalaisen pop-musiikin raadollisuuden ja olen itse mukana musiikin tuotannossa. Näin ollen esimerkiksi tutkimusasetelmaa ja -kysymystä suunnitellessa arvelin, että musiikin tekeminen ei itsessään ole ollut haastateltavieni pääasiallinen ansiotulojen lähde. Havaintoni 2010-luvun omaehtoisten urien prekaariudesta voivat heijastua tutkimuksen tuloksissa tai toisaalta ikäni voi näkyä uppoutumisvaiheen merkityksen korostamisessa omaehtoisten urien syntymisessä.

Tutkimustani ohjaa elämänkulkuanalyysin periaatteet, mutta käytännön analyysityön tein niin sanotun informoidun grounded theoryn periaatteita noudattamalla ATLAS.ti-ohjelmassa. Perinteisestä ja yksinomaan aineistolähtöisestä grounded theorystä (Glaser \& Strauss 2006 [1967]) poiketen informoidussa grounded theoryssä yhdistetään tutkimuskirjallisuudesta poimittuja käsitteitä aineistosta nouseviin kategorioihin (Thornberg 2012; Charmaz 2006; Mills ym. 2006: 26-28). Analyysiani ohjasi käsitteistö elämänkulkuanalyysistä ja alakulttuuri- ja skeneteoriasta. Koodasin haastattelulitteroinnit ensin täysin avoimesti toistuvasti esiinnousseiden teemojen mukaisesti. Toisella koodauskierroksella jäsensin aineistokoodit kategorioiksi, joita käyttämällä koodasin aineiston uudelleen. Tässä vaiheessa hyödynsin tutkimuskirjallisuuden käsitteistöä, kuten elämänkulun aksioomia. Yhdessä esiintyvistä kategorioista loin tutkimuksen tuloksena esitellyt neljä omaehtoisen uran vaihetta. Viimeisellä koodauskierroksella käytin omaehtoisen uran neljää vaihetta keskeisinä analyysikategorioina ja liitin kaikki muut luodut kategoriat ATLAS.ti:ssä johonkin neljästä elämänvaihekategoriasta, jolloin vaiheisiin kuuluvat elämänkulun tapahtumat tarkentuivat. Metodologista työskentelyä havainnollistetaan Taulukossa 1, jossa esitellään aineistossa havaitut 32 siirtymäkategoriaa ja se, miten useasti ne esiintyvät suhteessa omaehtoisen uran neljään vaiheeseen. Taulukko on tehty ATLAS.ti:n code co-occurence -työkalulla. Taulukko 1 on seuraavissa luvuissa esittelemäni varsinaisen analyysin apuväline. Analyysi on jaettu neljään omaehtoisen uran vaiheita seuraavaan alalukuun, joissa tutkin haastateltavien elämiä mikrotasolla toimijuuden, sosiaalisten suhteiden, akkumulaation ja toimijuuden aksioomien näkökulmista. Kussakin alaluvussa tuodaan esiin makrotasolla tapahtuneet yhteiskunnalliset muutokset, jotka ovat suhteessa omaehtoisten urien rakentumiseen. 
Taulukko 1. Elämänkulun siirtymien määrällinen ilmeneminen haastateltavien puheessa suhteessa analyysissä hahmottuviin omaehtoisen uran neljään vaiheeseen.

\begin{tabular}{|c|c|c|c|c|}
\hline Aineistosta hahmottuvat siirtymäkategoriat & $\begin{array}{l}\text { Ensi- } \\
\text { kosketus }\end{array}$ & $\begin{array}{l}\text { Uppoutu- } \\
\text { minen }\end{array}$ & $\begin{array}{l}\text { Toteutumi- } \\
\text { nen }\end{array}$ & Ylläpito \\
\hline "Aikatutkimus"2 & 0 & 0 & 0 & 3 \\
\hline Aikuistuminen & 0 & 0 & 0 & 3 \\
\hline Armeija & 1 & 0 & 0 & 0 \\
\hline Elävästä musiikista DJ:ksi & 0 & 0 & 1 & 0 \\
\hline ELMU:n puheenjohtajaksi & 0 & 0 & 1 & 0 \\
\hline Erkaantuminen & 0 & 0 & 1 & 4 \\
\hline Kaupunginvaltuusto & 0 & 0 & 4 & 1 \\
\hline Kiinteistölautakunta & 0 & 0 & 2 & 0 \\
\hline Lukion loppuminen & 3 & 3 & 0 & 0 \\
\hline Muodollisen koulutuksen lopettaminen & 0 & 2 & 1 & 1 \\
\hline Musiikin tekemisen "vakavoituminen" & 2 & 10 & 0 & 0 \\
\hline Musiikin tekemisen aloittaminen & 6 & 3 & 1 & 1 \\
\hline Musiikin tuottamisen aloittaminen & 5 & 0 & 0 & 0 \\
\hline Musiikkiin tutustuminen & 3 & 1 & 0 & 0 \\
\hline Musiikkitoiminnan "vakavoituiminen" & 1 & 3 & 0 & 0 \\
\hline Nuori aikuisuus & 4 & 5 & 0 & 1 \\
\hline Nuorisokulttuurin pariin & 3 & 2 & 0 & 1 \\
\hline Nuorisokulttuurin tutustuminen & 5 & 2 & 1 & 1 \\
\hline Nuorisokulttuurisen uran täysipäiväistyminen & 2 & 3 & 5 & 2 \\
\hline Opiskelu & 0 & 2 & 1 & 0 \\
\hline Opiskelujen lopettaminen & 0 & 2 & 2 & 1 \\
\hline Peruskoulun aloittaminen & 1 & 0 & 0 & 0 \\
\hline Post-Lepakkoluola & 0 & 0 & 0 & 1 \\
\hline Radio City & 1 & 7 & 7 & 2 \\
\hline Radio Helsinki & 0 & 0 & 0 & 1 \\
\hline Tanssimusiikin pariin & 0 & 0 & 1 & 0 \\
\hline Tapahtumatuotantotyöpaikan vaihto & 0 & 0 & 1 & 0 \\
\hline Toimijuuden vakiintuminen & 0 & 1 & 1 & 2 \\
\hline Työttömyys & 0 & 0 & 1 & 1 \\
\hline Vanhemmuus & 0 & 0 & 0 & 2 \\
\hline Yhdessä asuminen & 0 & 0 & 0 & 1 \\
\hline Yritystoiminta & 1 & 1 & 2 & 7 \\
\hline
\end{tabular}

2 Teemu Lehdon omasta toiminnastaan käyttämä ilmaisu, jolla hän viittaa muun muassa tyhjänä olevan kaupunkitilan edelleenvuokraukseen yhteistyössä kaupungin kanssa mutta myös esimerkiksi vuokrattujen tilojen saaman uuden elämän tarkkailuun (Lehto h2018). 


\section{Ensikosketus: tutustuminen nuorisokulttuuriin}

Ensikosketus-vaihe on omaehtoisen uran peruskivi. Haastateltavat tutustuivat musiikkiin ensin kuuntelijoina, mutta siirtymän myötä kolme heistä ryhtyi myös sen alkeelliseen tuottamiseen. Makrotason näkökulmasta haastateltavien lapsuus ja esiteini-ikä osuivat 1960- ja 1970-luvuille, jolloin pop- ja rock-musiikki kasvatti suosiotaan erityisesti nuorison parissa (esim. Bruun ym. 1998). Haastateltaville pop-musiikki tuli tutuksi ikätovereiden, sosiaalisten suhteiden, myötävaikutuksella. Omaehtoisen uran kannalta musiikkiin tutustuminen on käännekohta, jota ilman omaehtoinen ura ei olisi syntynyt. Pasin kertomus heijastelee myös "musiikillista epifaniaa" (Green 2016: 342.) Muisto sijoittuu nuorisotilaan:

[...] isommat jätkät toi sinne levyjä ja sit siel kertsissä kuunneltiin levyjä. [...] Siel mä sit ekaa kertaa kuulin kaikkii tämmösii niinku proto-heavy bändejä, Black Sabbathit ja tälläset klassikot. Sit mä tajusin et 'hei tällästä musaa on olemassa' ja aloin sitä 'lisää, lisää, lisää'. (Nikander h2018.)

Vaiheen aikana skenen sosiaaliset suhteet alkoivat vahvistaa yksilöiden nuorisokulttuurista toimijuutta itseään ruokkivan kehän kaltaisesti. Esimeriksi 1960-luvun puolivälissä Christian tutustui ensimmäisiin skene-tuttuihinsa, järjesti tämän kaveriporukan kanssa nuorisokulttuuritapahtumia ja perusti alkeellisen kulttuuritilan. Kun hän vielä opetteli tekemään psykedeelisiä valoefektejä, sai hän suhteidensa avulla paikan valosuunnittelijana kolmesta Helsingin seudun bändistä. Seuraavina vuosina hän alkoi uppoutua nuorisokulttuurin tekemiseen toden teolla valomiehenä. (Moustgaard h2018.)

Nuoruuteen kuuluu koulu ja ohjattu vapaa-ajanvietto. Tällaisen muodollisen ja aikuisten järjestämän toiminnan haastateltavat näkivät erillisenä nuorisokulttuurista, mutta niiden piirissä saadut kokemukset heijastuvat omaehtoisen uran alussa. Jyrki kertoo, että koulun piirissä musisointi oli vähäistä, ja koska se rajoittui institutionaaliseen kontekstiin, ei se edusta hänelle varsinaista nuorisokulttuurista osallisuutta: "Oli tietysti ollut koulussa niinku luokkabändi, jossa oli ite laulanut [...] ne oli sellasia koulujuttuja vaan, että ajatteli, että mä nyt oon tässä ihan passiivisena vaan.” (Jantunen h2018.) Teemu kokee, että hänen elämänsä keskeinen käännekohta tapahtui poliittisessa nuorisojärjestössä, jonka kautta hän altistui nuorisokulttuurille ja alkoi toimia sen piirissä. Teemulle Koijärven kuivattamista vastaan järjestetty protesti vuona 1979 oli keskeinen epifania, jonka voi tulkita siirtymänä uppoutumisvaiheeseen:

$[\mathrm{M}]$ enin sinne vähän niinku toimittajana, mutta palasin aktivistina. Ja sitä kautta sitten tuli tietenkin tämmönen tapa toimia [...] esittää se argumentti, 
että jos täällä on tyhjillään olevia taloja niin minkä takia näitä ei voi käyttää, esimerkiks nuorison ja kulttuurin käyttöön. Ja se itse asiassa jäi päälle, sitähän mä teen vieläkin. (Lehto h2018.)

Haastateltavat alkoivat siis uppoutua nuorisokulttuuriin vähittäin ensikosketuksen jälkeen, mikä korostaa uran vaiheiden välisten siirtymien limittäisyyttä. Uppoutuminen tapahtui toden teolla perus- tai toisen asteen koulutuksen jälkeen, jolloin siirtymä uuteen rooliin vapautti lisää aikaa ja antoi itsenäisyyttä. Pasi ei suorittanut toisen asteen koulutusta, vaan työskenteli satunnaisissa hanttihommissa jo ennen täysi-ikäisyyttä. Hän näkee, että teini-ikäisenä musiikin tekeminen oli hänelle koulutusta tärkeämpää, mikä enteilee omaehtoisen uran uppoutumisvaihetta (Nikander h2018). Lukioon jatkanut Christian taas korostaa, että koulun viemät resurssit olivat syy siihen, että hänen ja hänen kavereidensa nuorisokulttuuritilakokeilu jäi vain yhden kesän mittaiseksi eikä nuorisokulttuurinen toimijuus vielä kasvanut suurempiin mittoihin (Moustgaard h2018). Kimmo puhui suoremmin lukion jälkeen tapahtuneesta käännekohdasta, kun bändistä tuli elämän johtotähti ja hän uppoutui nuorisokulttuuriin: "[M] usiikki vei, vaikka sit tämmöset, vaeltelu Lapissa jatku jonnekin 20-vuotiaaks. Mut sit ehkä muulla lailla elämä muuttu, alko opiskelut ja parisuhteet, kaveripiiri vähän muuttu [...]. Sen aktiivisuuden vei sit kyl musiikki-, bänditoiminta." (Helistö h2018.)

\section{Uppoutuminen: nuorisokulttuurisen toimijuuden kasvu}

Uppoutuminen nuorisokulttuurin tekemiseen on suuri harppaus kohti omaehtoisen uran todeksi tulemista. Siirtyessään varhaisaikuisuuteen haastateltavat etsivät ikävaiheelle tyypillisesti (Arnett 2014) paikkaansa yhteiskunnassa kokeilemalla opiskelua ja erilaisia töitä. Esimerkiksi Kimmo sijaisti yhden lukukauden peruskoulussa ja aloitti luokanopettajaopinnot. Opiskeluaikanaan hän teki erilaisia fyysisiä kesä- ja osa-aikatöitä sekä pienimuotoisia toimitustöitä. (Helistö h2018.) Christianista tuli lukion jälkeen vuodeksi maanmittari Helsingin seudun kasvaviin lähiöihin. Hänen kertomuksensa työpaikan hankinnasta heijastelee aikakauden kulttuurista käsikirjoitusta, koska hän oli epävarma, voiko nuorisokulttuurilla elättää itsensä: "[H]akeuduin normaaliin duuniin. Mä ajattelin etten, jos jään roikkuu tähän niin kuumeiseen elämään, niin siit ei hyvää seuraa." (Moustgaard h2018.)

Uppoutumisvaiheessa nuorisokulttuurin rooli kasvoi haastateltavien elämässä. Kimmon, Pasin ja Jyrkin bändit saivat suosiota, minkä myötä he omaksuivat uuden roolin ja alkoivat myös tuottaa musiikkia. Kun heidän bändinsä siirtyivät amatööritasolta ammattimaisemmiksi, he ajan uuden aallon omaehtoisen kulttuurin hengessä (ks. esim. Bruun 1998) tekivät itse äänitteitä, järjestivät keikkoja ja suunnittelivat 
jonkinasteisesti tulevaisuutta. (Helistö h2018; Nikander h2018; Jantunen h2018.) Christian ja Teemu saivat ensimmäiset osa- ja määräaikaiset työpaikat musiikkitapahtumien tuottajina. He pyrkivät myös parantamaan musiikin toimintamahdollisuuksia (harjoitus- ja esitystilat, elävän musiikin asema) Elmun kautta ja olivat valtaamassa Lepakkoluolaa eli harjoittivat elämänkulkutoimijuutta. (Lehto h2018; Moustgaard h2018.) Myös Pasi sai skenen suhteiden kautta määräaikaisen työpaikan Lepakon ylläpitäjänä (Nikander h2018).

Lepakkoluola oli historiallisen ajan ja paikan luoma mahdollisuus haastateltavien sosiaalisten suhteiden kasvulle, mikä taas heijastui nuorisokulttuurin tekemiseen uppoutumisena. Tila tarjosi fyysiset puitteet, harjoitus- ja esiintymistiloja, mutta ennen kaikkea se integroi haastateltavat entistä laajempaan skeneen. Lepakkoluola oli sosiaalinen "magneetti", joka toi yhteen pääkaupunkiseudun (ja jopa Suomen) nuorisokulttuurisia toimijoita ja tihensi skenen sosiaalisia verkostoja (Helistö h2018; Rantanen 2000). Skenen sosiaaliset suhteet vahvistivat taas kehämäisesti toimijuutta suhteessa nuorisokulttuuriin. Tätä kuvastaa hyvin Jyrkin kertomus siitä, miten Lepakon skenen löytäminen oli hänelle reitti, jota kautta hän siirtyi aktiiviseen rooliin nuorisokulttuurissa. Tilaan mukaan tulo ja näin ollen toimijuuden aloittaminen edustaa siis käännekohtaa hänen elämässään: "huomasin olevani siellä melkeen niinku, en nyt joka päivä, mutta hyvin monena päivänä viikossa..." Hän jatkaa, että tämä "hengailu" johti lukuisien uusien tuttavuuksien solmimiseen ja oman nuorisokulttuurisen toimijuuden alkamiseen, kun häntä pyydettiin bändiin laulajaksi ja tapahtuma-DJ:ksi. (Jantunen h2018.)

Uppoutuminen kouli haastateltavia nuorisokulttuurista työpaikkaa varten. Skene muodosti omaehtoisen uran kannalta tärkeimmän alustan, jossa haastateltavat kerryttivät omaehtoisen uran vaatimia tietoja. Vaiheen aikana haastateltavat oppivat muun muassa tuottamaan musiikkitapahtumia ja tuntemaan helsinkiläistä popmusiikkia ja kaupunkikulttuuria, eli kerryttivät alakulttuurista pääomaa (Thornton 1995). Nämä olivat keskeisiä tietoja ja taitoja omaehtoisen uran kolmanteen vaiheeseen siirtymiselle. Vaihe vahvisti nuorisokulttuurista toimijuutta myös epifanioiden kautta kerryttämällä heidän odotushorisonttiinsa mahdollisuuden työskentelystä nuorisokulttuurin parissa. Kun nuorisokulttuurinen toiminta kasvoi, haastateltavat alkoivat saada siitä pienimuotoista toimeentuloa. Haastateltujen muusikoiden kertomuksissa toistui sama tarina musiikista saaduista palkkioista: ne olivat vaatimattomia (Helistö h2018; Jantunen h2018; Nikander h2018). Tulojen saaminen kumuloitui kuitenkin epifaniaksi nuorisokulttuurisen ammatin ja työuran mahdollisuudesta. Esimerkiksi Kimmo korostaa, että bänditoiminnan kautta hän "oppi ajattelemaan myös niinku musiikkia mahdollisena ammattina." (Helistö h2018.) 


\section{Toteutuminen: työtä ja toimeentuloa nuorisokulttuurista}

Toteutumisvaiheessa omaehtoiset urat tulevat todeksi, kun nuorisokulttuurinen toimija saa työpaikan nuorisokulttuurin tuotannossa ja valitsee pyrkiä muodostamaan uran sen parissa. Vaiheen aikana Christian, Teemu ja Kimmo keskeyttivät yliopisto-opintonsa ja päättivät ohjata toimijuutensa kohti nuorisokulttuuria. Christian hankki opiskelupaikan kauppakorkeakoulusta noin 30-vuotiaana 1979, juuri kun Lepakko oli vallattu. Hän opiskeli vuoden "aika hyvin", mutta keskeytti opintonsa keskittyäkseen Lepakkoluolaan: "[...] sit alko tulee niin paljon ratkastavii ongelmia, että... Ehkä ois pystyny opiskelee siinä ohessa, ehkä ei.” (Moustgaard h2018.) Hän siis valitsi keskittyä työelämässään nuorisokulttuuriin tietoisesti. Kyse on elämänkulun toimijuudesta, mutta myös käännekohdasta omaehtoisen uran varrella.

Radio City oli toinen historiallisen ajan ja paikan avaama mahdollisuus nuorisokulttuuristen urien synnylle, mutta samalla se oli nuorten toimijuuden seurausta. Christian ja Teemu olivat perustamassa kanavaa. Teemu kertoo, että kanavan perustaminen lähti hänen ehdotuksestaan YK:n nuorisovuotta 1985 edeltävässä seminaarissa. Elmun aktiivit alkoivat ajaa kanavaa eteenpäin, koska eivät uskoneet Helsingin kaupungin saavan nuorisokanavaa aikaiseksi lupauksistaan huolimatta. (Lehto h2018; ks. myös Kemppainen 2015: 173-175.) Neljä tutkimuksen haastateltavaa työllistyi Radio Cityyn joko hallintoon tai toimittajiksi. Teemu toimi radiokanavan taustaorganisaatiossa ja lyhyen aikaa myös toimittajana (Lehto h2018). Jyrkistä ja Kimmosta tuli kanavan toimittajia. Kumpikaan ei ollut suunnitellut toimittajan uraa, mutta he tarttuivat tilaisuuteen, minkä seurauksena heidän elämänkulussaan tapahtui käännekohta kohti omaehtoista uraa. Jyrkin työllistyminen kanavalle osoittaa, että Lepakon skenen sosiaaliset suhteet vaikuttivat myös tässä siirtymässä toimijuuden kasvuun. Christian pyysi Jyrkiä ohjelman tekoon, koska hän oli Lepakossa vietetyn ajan myötä "niinku huonekalu" tilassa (Jantunen h2018). Kun Kimmo siirtyi töihin Radio Cityyn, hän päätti lopettaa yliopisto-opintonsa. Kimmon kertomuksessa näkyy toimijuus, mutta myös ensikosketus-vaiheen aikana kumuloitunut identiteetti. Hän koki nuorisokulttuurisen ammattiaseman itselleen läheisemmäksi kuin perinteisenä pidetyn: "Mä koin heti, että toi olis ilman muuta mun juttu [...] kerta heitolla loppu mun opiskelut opettajankoulutuslaitoksella." (Helistö h2018.)

Jyrki ja Kimmo kokevat, että heidän valintaansa vaikutti heidän aiemmin kerryttämänsä tieto populaari- ja kaupunkikulttuurista sekä näiden erikoistuneista muodoista (Helistö h2018; Jantunen h2018) - siis alakulttuurinen pääoma. Kun alakulttuurin tuntemus oli keskeistä, ennen kaikkea alakulttuurisen pääoman sosiaalinen ulottuvuus oli tärkeä siirryttäessä julkiseen toimittaja-juontajan rooliin. Aikaisemman elämänkulkunsa aikana he olivat kerryttäneet ruumiillistettua alakulttuurista pääomaa ja edustivat skenen sisällä erilaisten kulttuuristen konstruktioiden ilmentymiä. 
Toisaalta he olivat myös alakulttuurin musiikkigenrejen asiantuntijoita, jotka toimittajina määrittivät skenen arvostuksen kohteita esimerkiksi valitsemalla kanavalla soitettavan musiikin (vrt. Thornton 1995: 55-56). Omasta roolistaan kanavalla Jyrki toteaa: " $[M] a ̈$ edustin sitä tiettyä ryhmää siellä. Mä olin niitten tyyppien, sit siel oli jotain muita tyyppei, jotka edusti vähän erilaisia. [...] koottiin vähän eri kulttuureista tekee sinne juttuja." (Jantunen h2018.)

Pasi ei työllistynyt Radio Cityyn, vaan hänen omaehtoinen uransa toteutui, kun hän ryhtyi kaupalliseksi tapahtumatuottajaksi 1980-luvulla. Siirtymä tapahtui vähittäin ja suunnittelematta: "Aluksihan noitten keikkojen ja klubien ja tapahtumien järjestäminen oli just for fun. Tehdään jotain, kun ei oo tässä muutakaan. Mutta sittehän mä työllistin itteni sillä ihan 10-15 vuotta." (Nikander h2018.) Myös Pasin siirtymän mahdollisti hänelle kertynyt alakulttuurinen pääoma ja kokemus musiikkituotannosta. Kaupallisen uran mahdollisti kuitenkin ennen kaikkea pop-musiikin suosion nousu (ks. esim. Muikku 2001: 251-257), historiallinen aika ja paikka. Radio Cityn perustaminen voidaan nähdä myös saman makrotason yhteiskunnallisen muutoksen seurauksena, sillä sen eksplisiittisiin tavoitteisiin .kuului nuorison suosiman pop-musiikin määrän lisääminen ääniaalloilla (Lehto h2018; Kemppainen 2015).

Kolmannen vaiheen aikana haastateltavat valitsivat nuorisokulttuurin kanssa työskentelyn, koska kokivat sen omakseen ja heillä oli vaadittavat tiedot ja taidot, kun mahdollisuudet omaehtoisen uran aloittamiseen aukenivat. Toteutumisvaiheessa haastateltavien koulutie keskeytyi, koska nuorisokulttuuri oli lähempänä heidän identiteettiään kuin koulutuksen kautta saatava ammattiasema. Toisin kuin monien alakulttuuriryhmien nuoria koskevien tutkimusten tuloksien mukaan (vrt. esim. MacDonald \& Shildrick 2007; Willis 1977), tämän tutkimuksen haastateltavien asenteet eivät olleet koulutusvastaisia. Toteutumisvaihetta leimaa myös erilaisten töiden ja urien rinnakkaisuus ja limittyneisyys: kaikki haastateltavat olivat edelleen mukana erilaisissa tapahtumatuotannoissa, joiden rinnalle tuli uusia vakituisempia töitä, kuten Radio City.

\section{Ylläpito: omaehtoisen uran jatkaminen}

Ylläpitovaiheessa omaehtoinen urapolku tulee pisteeseen, jossa toimija jatkaa mutta on myös pakotettu jatkamaan aikaisempaa työuraansa ja nuorisokulttuurisen identiteetin toteuttamista oman toimijuutensa varassa. Toteutumisvaiheen työpaikat kestivät vuosia, mutta niiden loputtua haastateltavat olivat tilanteessa, jossa heillä ei ollut perinteisen työelämän vaatimia taitoja tai muodollista pätevyyttä ja he lähestyivät 40 ikävuotta. He joutuivat kehittämään itselleen työpaikan, jossa voivat hyödyntää aikaisemman elämänkulkunsa aikana kertyneitä taitoja. Ylläpitovaiheessa 
omaehtoiset urat lähenevätkin perinteisiä työuria, joissa luovitaan aikaisemman työkokemuksen avulla. Tämä korostaa omaehtoisten urien olevan nimenomaan nuoruuden ikävaiheen kulttuuriseen toimijuuteen juurtuvia urapolkuja. Vaiheen aikana neljä viidestä haastateltavasta on perustanut yrityksiä, mikä heijastaa vaiheen merkitystä nimenomaan omaehtoisen uran taloudellisena ylläpitämisenä. Haastateltavien elämänkuluista on tunnistettavissa kolme ylläpitovaiheen tyyppitarinaa tai omaehtoisen uran "lopputulosta": 1) uuden nuorisokulttuurisen ammattiaseman löytäminen ja siinä jatkaminen, 2) uuden nuorisokulttuurisen ammatin löytäminen, mutta sen lopettaminen ja 3) erilliset ammatit toimeentulolle ja nuorisokulttuuriselle toiminnalle. Haastateltavat irtautuivat vaiheen aikana myös Lepakosta, skenestä ja toisistaan. Kukaan haastateltavista ei ole kuitenkaan täysin irtautunut osallistumisesta musiikkitapahtumiin toimijaroolissa.

Jyrkin ja Kimmon urat seuraavat ensimmäistä tyyppitarinaa. Jyrki jatkaa yhä radiouraansa Radio Helsingin juontajana. Nuorisokulttuurin merkityksellisyys jatkuu hänen elämässään: Vuonna 2000 hän päätyi tekemisiin uuden radiokanavaprojektin (myöh. Radio Helsinki) kanssa ja valitsi jatkaa toimittajan uraansa kanavalla. Hän koki kanavan omakseen, koska sen toimintaperiaatteet, esimerkiksi soittolistojen puuttuminen, edustavat hänelle varhaisen Radio Cityn henkeä. Hän on myös tehnyt televisioalan töitä ja jatkaa satunnaisena tapahtuma-DJ:nä. (Jantunen h2018.) Kimmo lopetti radiotyön 1990-luvun alussa, kun hänet valittiin kunnanvaltuustoon vuosiksi 1993-1996 ja uudelleen kolmena kautena 2001-2012. Hän kokee valtuustoaikansa olevan nuorisokulttuurisen toimijuutensa ja osallisuutensa ansiota. Hän asettui ehdolle Teemun kannustamana ja näkee tulleensa valituksi Radio Cityn luoman julkisuuden avittamana. Kimmo haki 1990-luvulla töihin markkinointi- ja mainosalalle, mutta ei tullut valituksi. Näin ollen hän joutui hankkimaan toimeentulonsa olemassa olevien nuorisokulttuuristen taitojensa varassa. Vuosikymmenen aikana Kimmo tuotti äänitteitä, järjesti tapahtumia ja oli Lepakossa perustamassa klubia, joka yhdistää taideperformanssit ja saunomisen. Kun Lepakko purettiin 1999, klubi alkoi kiertää kulttuuritilaisuuksia ja Kimmo hankki sille toiminimen. Vuonna 2006 Kimmon yritys vuokrasi Arla Saunan ja Kimmosta tuli saunayrittäjä. Lisäksi hän toimii kulttuuri- ja musiikkituottajana. (Helistö h2018.)

Toista tyyppiä edustavat Christian ja Pasi perustivat ylläpitovaiheessa oman alansa yritykset, mutta joutuivat lopettamaan ne ja etsimään uusia toimeentulon lähteitä. Muita vanhempi Christian siirtyi uran ylläpitovaiheeseen jo 1980-luvulla, kun hänestä tuli toimitusjohtaja yhdessä muiden skenen toimijoiden kanssa perustamaansa yritykseen, Radio Cityyn (Moustgaard h2018). Kanavan myynnin jälkeen Christian jatkoi media-alalla perustamalla kaapelitelevisiokanava ATV:n vuonna 1999. Yritys teki konkurssin 2003, mikä edusti Christianille taloudellisesti "henkilökohtaista katastrofia". ATV:n jälkeen Christian toimi muutaman vuoden kaupunkikulttuurilehti 
Nöjesguidenin suomalaisjaoston johtajana, minkä jälkeen hän on toiminut kulttuurialan konsulttina ja lukuisten alan hallituksien jäsenenä. (Moustgaard h2018.) Luottamustehtävät korostavat Christianille vuosien varrella kertynyttä tietotaitoa kulttuurintuotannosta, mutta ennen kaikkea hänen toiminnassaan kerryttämiään laajoja sosiaalisia suhteita.

Pasi siirtyi ylläpitovaiheeseen, kun alkoi järjestää musiikkitapahtumien lomassa nuorisokulttuurista erillisiä tapahtumia, kuten yritysten virkistäytymispäiviä, varmistaakseen toimeentulonsa. Tapahtumista Pasi puhuu "firmakisoina", millä hän korostaa eroa omaa identiteettiään heijastelevaan aikaisempaan toimintaansa. Hänen tapahtumatuottajauransa loppui 2000-luvun taitteessa. Hän kertoo, ettei hänellä ollut enää kosketusta nuorempien sukupolvien kuuntelemaan musiikkiin, toisin sanoen hän oli menettämässä otteensa alakulttuurisesta pääomasta (Thornton 1995), minkä takia työ vaikeutui. Pasi vaihtoi alaa ja perusti käytettyä audiotekniikkaa myyvän yrityksen, jossa hyödynsi kerryttämäänsä ammattitaitoa musiikin ja tapahtumien tuotannosta. Kymmenen vuotta myöhemmin historiallisen ajan tuoma kulttuurinen muutos puuttui peliin: kun käytetyn tavaran suoramyynti yleistyi internetissä, kivijalkamyymälä ei enää kannattanut. Sen jälkeen Pasi on hankkinut ansionsa satunnaisilla töillä esimerkiksi levykauppojen osa-aikamyyjänä, ajamalla taksia ja kunnostamalla vanhoja huonekaluja myytäväksi. Lisäksi Musta Paraati -yhtye teki paluun lavoille ja studioon 2010-luvun loppupuolella. Pasi soitti yhtyeessä vuoteen 2018. (Nikander h2018.)

Kolmatta tyyppitarinaa edustava Teemu on luonut kaksi selkeästi erillistä uraa: yhden, josta saa toimeentulonsa, ja toisen, joka mahdollistaa nuorisokulttuurisen toiminnan jatkamisen. Hän erkaantui Radio Citystä 1980-luvun lopulla ja alkoi järjestää kaupunkifestivaaleja ja muita kulttuuritapahtumia osa-aikayrittäjänä, työskenteli IT-alalla sekä toimi varajäsenenä Helsingin kaupungin kiinteistölautakunnassa. Kirjoitushetkellä hän toimii sekä IT-konsulttina että "aikatutkijana", jolla hän tarkoittaa muun muassa tyhjillään olevan kaupunkitilan edelleenvuokraamista kulttuuri- ja muuhun käyttöön. (Lehto h2018.)

Työuran ylläpitoon siirtymisestä kertoo myös se, että omaehtoisen uran viimeisessä vaiheessa haastateltavat kertoivat joutuneensa sopeuttamaan toimintaansa aikuisilta odotettavaan taloudelliseen itsenäisyyteen, lapsien saamisen luomiin velvollisuuksiin ja abstraktimpaan aikuistumiseen (ks. Davis 2012: 64). Yrittäjyys itsessään on esimerkki sopeutumisesta ja ikään kuin sinetti haastateltavien ylläpitovaiheeseen siirtymiselle. Lapsien saamisen koettiin yksiselitteisesti rajoittaneen mahdollisuuksia osallistua nuorisokulttuuriin ajankäytöllisesti (Jantunen h2018) ja muuttaneen toimintaa taloudellisesti turvallisemmaksi. Muutos on kuitenkin voinut tapahtua kulttuuristen ihanteiden hinnalla, kuten Pasi kertoo: "Sitku se oli omasta liksasta kiinni 
niin vähemmän otti riskejä. Ehkä vähän olis välil pitänykin ottaa niit riskejä, kaiken maailman härö-bändejä soittamaan...” (Nikander h2018.) Myös Teemu kuvaa, miten ikääntyminen on muuttanut hänen toimintaansa. Uran kolmannen ja neljännen vaiheen nivelkohdassa hän kävi läpi kasvuprosessin, jonka myötä hän kyseenalaisti nuoruutensa toimintamallien etiikkaa ja mielekkyyttä. Kasvuprosessi on tarkoittanut tiiviimpää yhteistoimintaa kaupungin ja muiden instituutioiden kanssa: "[N]ykyään se on, että solmitaan sopimuksia ja vuokrataan niitä ja neuvotellaan vuokrasopimuksia. Se ei oo enää niin raadollista, että mennään ikkunasta sisään.” (Lehto h2018.)

Kasvatustieteilijä Kathryn Ecclestonen (2009: 12) mukaan elämänkulun siirtymien lopputuloksena ihmisestä "tulee joku" henkilökohtaisella tasolla, mutta myös ammatillisesti. Näkemys tulee esiin myös tässä tutkimuksessa: kaikki haastateltavat kokivat, että heidän nykyinen työnsä, ja uransa ylipäätään, juontuu nuorisokulttuuriseen toimintaan ja että he jatkavat nuoruutensa altruististen motiivien toteuttamista nykyisessä ammatissaan. Heidän elämänkulkunsa muotoutumisen ja työuran lopputuloksen kannalta keskeisiä käännekohtia ovat olleet nuorisokulttuurin pariin johtaneet tekijät ja toimijuus sen piirissä, koska ne ovat edistäneet toimijuutta ja urasekä elämänvalintoja. Esimerkiksi Teemu kertoo kokeneensa "luonnollisesti vetoa" ryhtyä toimijaksi, kun hän näki nuorisokulttuuria kohdeltavan epätasa-arvoisesti (Lehto h2019). Epätasa-arvoinen kohtelu ilmeni muun muassa niin, että viihdeja korkeakulttuuritapahtumien huviveroprosentti oli eri, Helsingissä oli katusoittokielto ja kaupungista puuttui pop-musiikille riittävät harjoitus- ja esiintymispaikat (ks. Bruun ym. 1998: 241). Teemu erotteleekin toimintansa merkitykselliseen "tehtävään" ja toimeentulon takaavaan "työhön" (ks. myös Andres \& Wyn 2010: 159):

Kun mä en ikinä kuitenkaan kokenut olevani duunissa, vaan mulla on ollut enemmänkin tehtävä. Ja se erottaa sen asenteen, että jos joskus on ollut jossain niinku työtehtävässä äitiyslomasijaisena tai kesäapulaisena. Mutta kuitenkin enemmänkin ollut aina tehtävä. Planeetta Maalla täällä pohjosessa, Helsingin kaupungissa. (Lehto h2018.)

Ylläpitovaiheessa haastateltavat toimivat tai ovat toimineet erilaisissa kaupunki- ja pop-kulttuurin tuotannollisissa rooleissa, minkä on mahdollistanut kulttuuristen muotojen monipuolistuminen, yleistyminen ja niihin liittyvän kaupallisen infrastruktuurin kasvu Helsingissä 1990-luvulla (Mäenpää 2005; Ruoppila \& Cantell 2000). Elämänkulkujen mikrotasolta makrotasoa tarkastellessa voidaan myös todeta, että ylläpitovaiheessa haastateltavat ovat olleet luomassa ja vakiinnuttamassa tämänkaltaista kulttuuria Helsinkiin. 


\section{Yhteenveto ja keskustelu}

Olen tarkastellut nuorisokulttuurin, erityisesti musiikin, parissa muodostuneita omaehtoisia uria (DIY career) elämänkulun ja sen viiden aksiooman (toimijuus, sosiaaliset suhteet, siirtymät ja niiden ajoitus, kumulaatio sekä historiallinen aika ja paikka) kautta. Tästä näkökulmasta omaehtoinen ura hahmottuu neljästä vaiheesta rakentuvana: ensikosketus, uppoutuminen, toteutuminen ja ylläpito. Aineiston omaehtoiset urat koostuvat sarjoista erilaisia määräaikaisia työtehtäviä, ovat epävarmoja ja joskus myös taloudellisesti niukkoja. Urien muototumista on ohjannut halu parantaa pop-musiikin ja muun nuoriso- ja kaupunkikulttuurin asemaa Helsingissä. Havaitsin analyysissä kolme erilaista urapolkujen tyyppitarinaa: 1) nuorisokulttuurisen toiminnan jatkuminen ammatillisesti työpaikassa, 2) nuorisokulttuurisen ammatin löytäminen, mutta sen lopettaminen ja uusien ammattiasemien hankkiminen ja 3) kahtia jakautunut työura, jossa kulttuuriaktivismi jatkuu erillisenä urapolkuna toimeentulon takaavasta ammatista.

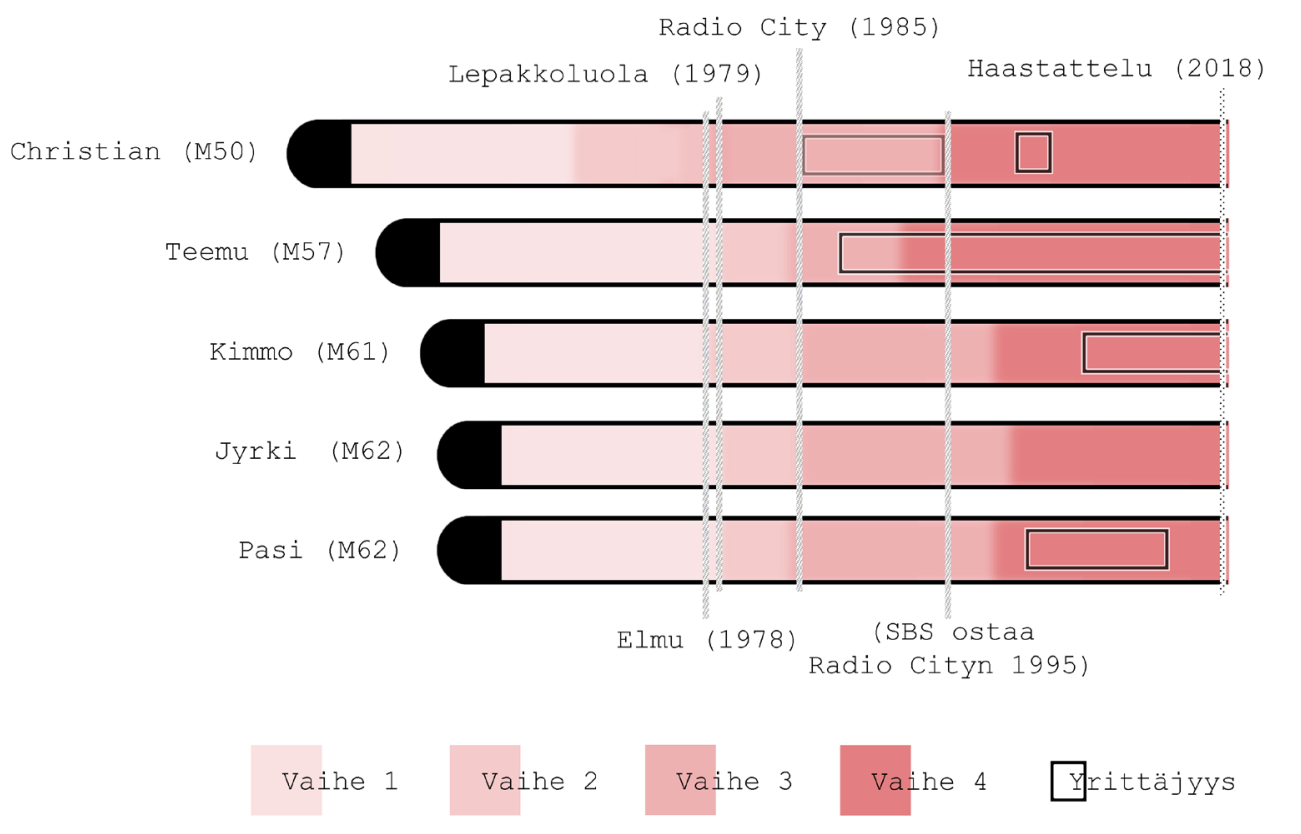

\section{Kuvio 1. Lepakkoluolan nuorisokulttuuristen toimijoiden elämänkulkujen ja työurien vaiheet.}

Tutkimukseni mukaan omaehtoiset urat etenevät vaiheittain tiettyjen, osin ikäsidonnaisten elämäntapahtumien myötä. Uran neljä vaihetta ovat osittain päällekkäisiä ja niiden väliset siirtymät limittäisiä (ks. kuvio 1). Ensikosketus nuorisokulttuuriin tapahtuu teini-iässä, kun henkilö tutustuu nuorisokulttuuriin ja mahdollisesti alkaa toimia sen parissa. Peruskoulu ja toinen aste rajoittavat nuorisokulttuurista toimijuutta tässä vaiheessa. Uppoutuminen tapahtuu varhaisaikuisuudessa, kun henkilö 
etsii omaa paikkaansa yhteiskunnassa ja osallisuus nuorisokulttuurissa ja sen tuottamisessa lisääntyy. Tämän tutkimuksen haastateltavat tulivat tässä vaiheessa osaksi Lepakon skeneä. Toteutuminen viittaa ainakin suhteellisen säännölliseen ja kokonaisvaltaiseen työllistymiseen ja toimeentuloon nuorisokulttuurin tuotannossa. Kyseiseen vaiheeseen siirtyessään haastateltavat valitsivat työn nuorisokulttuurin parissa yli muiden pyrintöjensä. Ylläpitovaiheen aikana henkilö erkaantuu suorasta skene-osallisuudesta, ylläpitää työuraansa aiemmin kerryttämiensä tietojen, taitojen ja verkostojen varassa sekä säilyttää skenessä omaksumansa identiteetin, maailmankatsomuksen ja kokemuksen omasta paikastaan yhteiskunnassa.

Tarkasteltaessa skene-osallistumista pitkittäisnäkökulmasta huomataan, että nuorisokulttuurisen toimijan skene-osallistuminen ei pääty Alastair Gordonin (2014) kolmiportaisen jaottelun (periferia, semiperiferia ja ydin) mukaisesti skeneä uudelleentuottavaan ytimeen, mutta ei myöskään ytimestä irrottautumiseen. Toteutumisvaiheen ydinroolin jälkeen tämän tutkimuksen haastateltavat ovat jatkaneet osallistumiseen juontuvien ihanteiden vaalimista vielä vuosikymmeniä myöhemmin ja olleet suhteessa skeneen semiperiferisessä asemassa. Nuorisokulttuuritoimijuuden läpi elämän jatkuva vaikutus tukeekin tutkimuksia (esim. Hodkinson 2016; Bennett 2013), jotka ovat haastaneet aiemmassa tutkimuksessa (esim. Vuori 1971: 110) vallalla olleen käsityksen nuorisokulttuuriin osallistumisesta väliaikaisena ja "luonnollisesti ohimenevänä” elämänvaiheena. Elämäntarinahaastattelun jälkiviisaudella onkin mielekkäämpää puhua nuorisokulttuurisen osallistumisen muodonmuutoksesta kuin sen loppumisesta (ks. myös Peipinen 2018), mitä korostaa myös oman toiminnan sopeuttaminen aikuisuuden rooleihin (ks. Davis 2012).

Voin todeta, että tutkimukseni teoreettismetodologinen apparaatti - grounded theoryn, elämänkulkuanalyysin ja muistitietotutkimuksen yhdistäminen - toimii hyvin. Kokonaisuus toimii myös Woodmanin ja Bennettin (2015) peräänkuuluttaman nuorisokulttuuriin osallistumisen ja siirtymien tutkimuksen yhdistävänä välineenä. Muistitiedon subjektiivisuus mahdollistaa usein vaikeasti tavoitettavien menneisyyden toiminnalle annettujen merkitysten analysoinnin. Elämänkulkuanalyysin viisi aksioomaa sopivat hyvin informoidun grounded theoryn (Thornberg 2012) tutkimuskirjallisuuslähtöisiksi kategorioiksi. Haastatteluaineiston eritteleminen sekä tutkimuskäsitteiden että aineistolähtöisten kategorioiden avulla auttoi tavoittamaan yksityiskohtaisesti elämänkulun siirtymät, käännekohdat ja muut keskeiset tapahtumat sekä vaikutussuhteita nuoruuden toiminnan ja aikuisuuden työelämän ja arvomaailman välillä.

Elämänkulun viiden aksiooman näkökulmasta ensisijaisesti yhteiskunnallinen muutos mahdollisti omaehtoiset urat: haastateltavien elämän aikana suosiotaan kasvattanut pop-musiikki ja kaupunkikulttuurin esiinmarssi Helsingissä loivat 
työllistymismahdollisuuksia nuorisokulttuurin tuottajille. Keskeisin yksittäinen historiallinen tapahtuma nuorisokulttuuriin uppoutumisen ja sen seurauksena omaehtoisten urien muotoutumisen kannalta on ollut Lepakkoluolan valtaus. Lepakossa toiminut skene integroi haastateltavat laajempiin verkostoihin ja loi konkreettisia toiminta- ja työllistymismahdollisuuksia. Myös vuonna 1985 tilassa toimintansa aloittaneen Radio Cityn luomat työpaikat olivat tärkeä reitti omaehtoisen uran toteutumiseen. Nämä tapahtumat heijastuvat haastateltavien elämänkuluissa käännekohtina, sillä ne avasivat uudenlaisia odotushorisontteja ja ohjasivat tekemään elämänkulkuun keskeisesti vaikuttaneita päätöksiä. Keskeisimpiä käännekohtia omaehtoisen uran syntymisessä ovat olleet pop-musiikkiin tutustuminen ja sen myötä skeneen osallistuminen, oma toimijuus ja sen kasvu uppoutumisvaiheessa.

Totesin analyysissä sosiaalisten suhteiden ja toimijuuden aksioomien kietoutuneen nuoruudessa yhteen ja toimineen itseään ruokkivan kehän kaltaisesti: skene-toimijoihin tutustumisen myötä haastateltavat siirtyivät passiivisen osallistujan roolista aktiivisiksi nuorisokulttuurin toimijoiksi, mikä syvensi skeneen kuulumista. Skenen sosiaaliset suhteet vahvistivat haastateltavien toimijuutta omaehtoisen uran kolmen ensimmäisen vaiheen ajan. Haastateltavat kertoivat, että saivat nuoruudessaan pontta elämänmittaiselle toimijuudelleen, kun halusivat vaikuttaa nuorisokulttuuria rajoittaviin yhteiskunnallisiin rakenteisiin. Haastateltavien elämänkulussa nuorisokulttuurin parissa alkanut pyrkimys toimia omaehtoisesti ja edistää kulttuurisia päämääriä heijastuu heidän toimijuutensa suunnassa. Myöhemmässä elämässään he ovat jatkaneet omaehtoisen kulttuurin siivittämällä tiellä ja rakentaneet työuransa kulttuurialalla.

Kolmannen ja neljännen vaiheen aikana haastateltavat sopeuttivat toimintaansa aikuisilta odotettuun rooliin. Elämänkulun ajoittuminen ohjasi siis elämän tapahtumia ja yksilöllisen toimijuuden suuntaa. Elämänkulkuanalyysi näkee elämän aina kumuloituvan aikaisempien tapahtumien ja kokemuksien päälle. Haastateltavat kertoivat käyneensä läpi nuoruudessaan musiikkiin ja nuorisokulttuuriin liittyviä epifanioita, erityisesti omaehtoisen uran alkuvaiheissa.Yhdessä nämä psykologiset itseymmärryksen hetket kumuloituivat käsitykseksi oman elämän toiveista ja haluista, siis identiteetin osaksi. Vähittäin haastateltavien odotushorisonttiin kertyi myös ajatus omaehtoisen uran mahdollisuudesta. Haastateltaville kasautui myös omaehtoisen uran vaatimaa tietotaitoa ja alakulttuurista pääomaa läpi elämänkulun teini-ikäisestä alkaen. Alakulttuurinen pääoma oli keskeinen resurssi siirtymiselle ensimmäiseen vakiintuneeseen nuorisokulttuurin tuotantoon liittyvään työpaikkaan ja näin ollen omaehtoisen uran toteutumiselle.

Alakulttuurisen pääoman näkökulmasta ajallinen, elämän mittainen, ulottuvuus tuo esiin, miten joissain konteksteissa jopa haitallisena näyttäytyvä pääoma on muuttunut 
haastateltavien elämänkulun aikana legitiimiksi ja hyväksytyksi kulttuuriseksi pääomaksi (vrt. Threadgold 2015; ks. myös Thornton 1995: 12). Alun alkaen haastateltavien kulttuuriset käytännöt, kuten heidän pop-musiikkimakunsa tai Lepakon valtaus, asettuivat vastatusten 1980-luvun arvomaailman kanssa. Heidän toimintansa arvo on tunnustettu yleisesti vasta vuosikymmeniä myöhemmin, kun Lepakon sukupolvi on asettunut vaikutusvaltaisiin asemiin yhteiskunnassa. Nykypäivänä haastateltavien edustamat alakulttuurit ovat toisinaan legitiimiä ja tunnustettua suomalaista kulttuuria, ja tutkimuksen haastateltavat ovat juhlistettuja ja kunnioitettuja kulttuurialan ammattilaisia. Haastateltavistani tehdyissä mediakirjoituksissa heidät kehystetään usein vasten heidän taustaansa Lepakossa. Ennen kaikkea heidän toimintansa kulttuurista arvonnousua voidaan tarkastella suhteessa heidän jokapäiväisen työnsä hedelmiin ja kerrannaisvaikutukseen 2020-luvun Helsingissä. Esimerkkeinä haastattelemieni lepakkoluolalaisten ansioista voi mainita Radio Helsingin, Sauna Arlan, Lapinlahden sairaala-alueen kulttuurikäytön, Kaapelitehtaan ja kukoistavat omaehtoisen musiikin skenet. 


\section{Lähteet}

\section{Tutkimusaineisto}

\section{Haastattelut}

Moustgaard, Christian (h2018) Helsinki 22.8.2018. Digitaalisesti tallennettu. Helistö, Kimmo (h2018). Helsinki 7.8.2018. Digitaalisesti tallennettu. Lehto, Teemu (h2018). Helsinki 7.8. ja 20.8.2018. Digitaalisesti tallennettu. Jantunen, Jyrki (h2018). Helsinki 21.8. ja 23.8.2018. Digitaalisesti tallennettu. Nikander, Pasi (h2018). Helsinki 6.9.2018. Digitaalisesti tallennettu. Kaikki haastattelut Juho Hänninen. Aineisto kirjoittajan hallussa.

\section{Kirjallisuus}

Atkinson, Robert (1998) The life story interview. Los Angeles: Sage. https://doi.org/10.4135/9781412986205

Abrams, Lynn (2016) Oral History Theory. Oxon \& New York: Routledge. https://doi.org/10.4324/9781315640761

Andres, Lesley \& Wyn, Johanna (2010) The making of a generation:Young adults in Canada and Australia. Toronto: Toronto University Press.

Arnett, Jeffrey Jensen (2014) Emerging adulthood: The winding road from the late teens through the twenties. Oxford: Oxford University Press. https://doi.org/10.1093/acprof:oso/9780199929382.001.0001

Bennett, Andy (2001) Cultures of Popular Music. Buckingham: Open University Press.

Bennett, Andy (2004) "Consolidating the Music Scenes Perspective". Poetics 32:3-4, 223-234. https://doi.org/10.1016/j.poetic.2004.05.004

Bennett, Andy (2013) Music, style, and aging: Growing old disgracefully? Philadelphia: Temple University Press.

Bennett, Andy (2018) "Youth, Music and DIY Careers". Cultural Sociology 12:2, 133-139. https://doi.org/10.1177/1749975518765858

Berg, Päivi \&Ylöstalo, Tiina (2020) "Harrastuksesta työksi”. Hyvää työtä! Nuorisobarometri 2019. Toim. Lotta Haikkola \& Sami Myllyniemi. Suomi: Valtion nuorisoneuvosto \& Nuorisotutkimusseura / Nuorisotutkimusverkosto. https:/tietoanuorista.fi/wp-content/uploads/2020/12/nuorisobarometri2019netti.pdf (luettu 6.10.2021)

Bruun, Seppo \& Lindfors, Jukka \& Luoto, Santtu \& Salo, Markku (1998) fee jee jee: Suomalaisen rockin historia. Porvoo: WSOY. 
Charmaz, Kathy (2006) Constructing Grounded Theory: A Practical Guide Through Qualitative Analysis. California: Sage Publications.

Davis, Johanna (2012) "Punk, ageing and the expectations of adult life". Ageing and Youth Cultures: Music, Style and Identity. Toim. Andy Bennett \& Paul Hodkinson. Lontoo ja New York: Berg.

Denzin, Norman K. (2001) Interpretive Interactionism. California: Sage Publications. https://doi.org/10.4135/9781412984591

Ecclestone, Kathryn (2009) "Lost and found in transition: Educational implications of concerns about 'identity', 'agency' and 'structure'". Researching Transitions in Lifelong Learning. Toim. John Field \& Jim Gallacher \& Robert Ingram, Robert. Lontoo \& New York: Routledge.

Elder Jr., Glen H. (1994) "Time, human agency, and social change: Perspectives on the life course". Social psychology quarterly 57:1, 4-15. https://doi.org/10.2307/2786971

Fingerroos, Outi (2003) "Refleksiivinen paikantaminen kulttuurien tutkimuksessa". Elore 10(2). https://doi.org/10.30666/elore.78407

Fingerroos, Outi \& Haanpää, Ulla (2006) "Muistitietotutkimuksen ydinkysymyksiä". Muistitietotutkimus: Metodologisia kysymyksiä. Toim. Outi Fingerroos \& Riina Haanpää \& Anne Heimo \& Ulla-Maija Peltonen. Helsinki: Suomalaisen kirjallisuuden seura.

Gecas, Viktor (2003) "Self-agency and the life course". Handbook of the life course. Toim. Jeylan T. Mortimer \& Michael J. Shanahan. Boston: Springer. 369-388. https://doi.org/10.1007/978-0-306-48247-2_17

Giddens, Anthony (1984) The Constitution of Society. Cambridge: Polity Press.

Glaser, Barney G. \& Strauss, Anselm L (2006 [1967]) The Discover of Grounded Theory: Strategies for Qualitative Research. New Brunswick ja Lontoo: Aldine Transaction.

Glass, Pepper G. (2012) "Doing scene: Identity, space, and the interactional accomplishment of youth culture". Fournal of Contemporary Ethnography 41:6, 695-716. https://doi.org/10.1177/0891241612454104

Gordon, Alastair (2014) "Subcultural Entrance Practices in UK Punk Culture". Subcultures, Popular Music and Social Change. Toim. The Subcultures Network. Iso-Britannia: Cambridge Scholars Publishing.

Green, Ben (2016) '"I always remember that moment': Peak Music Experiences as Epiphanies". Sociology 50:2, 333-348. https://doi.org/10.1177/0038038514565835

Haenfler, Ross (2018) "The Entrepreneurial (Straight) Edge: How Participation in DIY Music Cultures Translates to Work and Careers”. Cultural Sociology 12:2, 174-192. https://doi.org/10.1177/1749975517700774 
Heiskanen, Ilkka \& Mitchell, Ritva (1985) Lättähatuista punkkareihin: Suomalaisen valtakulttuurin ja nuorisokulttuurien kohtaamisen kolme vuosikymmentä. Helsinki: Otava.

Helistö, Kimmo (2018) "Lepakon korkeakoulu". Miksei aina voi olla perjantai80-luvun Radio City 96,2. Toim. Taina Värri. Helsinki: broholmen13.

Hesmondhalgh, David \& Baker, Sarah (2011) Creative Labour: Media Work in Three Cultural Industries. Lontoo: Routledge.

Hitlin, Steven \& Johnson, Monica Kirkpatrick (2015) "Reconceptualizing agency within the life course: The power of looking ahead". American fournal of Sociology 120:5, 1429-1472. https://doi.org/10.1086/681216

Hodkinson, Paul (2016) "Youth Cultures and the Rest of Life: Subcultures, PostSubcultures and Beyond". Fournal of Youth Studies 19:5, 629-645. https://doi.org/10.1080/13676261.2015.1098778

Häkkinen, Antti (2012) "Johan Adolf Kock, elämänkulkuanalyysi ja historia". Historiallinen Aikakauskirja 110:4, 378-389.

Hänninen, Juho (2019) The Four Stages of a DIY Career: The Life Courses and Careers of Youth Culture Practitioners from Lepakkoluola and the Helsinki Scene of the Early 1980s. Helsingin yliopisto. Pro gradu -tutkimus.

Hänninen, Juho (2021) "Rehellistä musiikkia Sherwoodissa: Skene- ja alakulttuuriteoriasta 1970- ja 1980-lukujen keravalaisen musiikkikulttuurin valossa”. Musiikin suunta 43:1. http://musiikinsuunta.fi/2021/05/08/rehellistamusiikkia-sherwoodissa-skene-ja-alakulttuuriteoriasta-1970-ja-1980-lukujenkeravalaisen-musiikkikulttuurin-valossa/ (luettu 30.6.2021)

Jian, Miaoju (2018) "The survival struggle and resistant politics of a DIY music career in East Asia: case studies of China and Taiwan". Cultural Sociology 12:2, 224-240. https://doi.org/10.1177/1749975518756535

Kemppainen, Pentti (2015) Radio kuuluu kaikille! Kaupallisen radion historia Suomessa. Helsinki: Into.

Kohli, Martin (2007) "The institutionalization of the life course: Looking back to look ahead." Research in human development 4:3-4, 253-271.

Kok, Jan (2007) "Principles and prospects of the life course paradigm." Annales de démographie historique 1, 203-230. https://doi.org/10.3917/adh.113.0203

Kurkela, Vesa (2003) "Eriytyvien yhteisöjen aika: vuodet 1963-90". Suomen musiikin historia: Populaarimusiikki. Toim. Pekka Jalkanen \& Vesa Kurkela. Porvoo: WSOY.

Lindfors, Jukka \& Salo, Markku \& Väänänen, Ritva (1988) Nupit kaakkoon: Elmu kymmenen vuotta. Helsinki: Elävän musiikin yhdistys Ry.

Lähteenmaa, Jaana (2000) Myöhäismoderni nuorisokulttuuri: Tulkintoja ryhmistä ja ryhmiin kuulumisten ulottuvuuksista. Helsinki: Nuorisotutkimusverkosto / Nuorisotutkimusseura. 
MacDonald, Robert, \& Shildrick, Tracy (2007) "Street corner society: leisure careers, youth (sub)culture and social exclusion". Leisure studies 26:3, 339355. https://doi.org/10.1080/02614360600834826

Mills, Jane \& Bonner, Ann \& Francis, Karen (2006) "The Development of Constructivist Grounded Theory". International fournal of Qualitative Methods 5:1, 25-35. https://doi.org/10.1177/160940690600500103

Muikku, Jari (2001) Musiikkia kaikkiruokaisille: suomalaisen populaarimusiikin äänitetuotanto. Helsinki: Gaudeamus.

Mäenpää, Pasi (2005) Narkissos kaupungissa:Tutkimus kuluttaja-kaupunkilaisesta ja julkisesta tilasta. Helsingin yliopisto. Väitöskirja.

Peipinen, Vesa (2018) From Subculture to Lifestyle: The Meaning of Squatting in the Life Courses Among Squatter Activists in Helsinki. Tampere: Tampereen yliopisto. Pro gradu tutkimus.

Peltonen, Matti (2001) "Clues, margins, and monads: The micro-macro link in historical research". History and Theory 40:3, 347-359.

Rantanen, Miska (2000) Lepakkoluola: Lepakon ja liekkihotellin tapahtumia ja ihmisiä 1940-1999. Helsinki: WSOY.

Ruoppila, Sampo \& Timo Cantell (2000) "Ravintolat ja Helsingin elävöityminen." URBS: Kirja Helsingin kaupunkikulttuurista. Toim. Stadipiiri. Helsingin kaupungin tietokeskus: Helsinki.

Seppälä, Pauliina \& Hellman, Matilda (2014) "A as in atmosphere, Z as in Zeitgeist: Trajectories in Helsinki dance club symbolism in the 1990s." International fournal of Cultural Studies 17:4, 327-345. https://oi.org/10.1177/1367877913486533

Sommar, Heidi (2013) "Paluu Koijärvelle". Yle: Elävä arkisto: https://yle.fi/aihe/artikkeli/2013/04/23/paluu-koijarvelle (luettu 2.5.2021)

Skaniakos, Terhi (2021) "The emergence of Suomirock in the 1970s and 1980s". Made in Finland: Studies in Popular Music. Toim. Toni-Matti Karjalainen \& Kimi Kärki. New York: Routledge. https://doi.org/10.4324/9780429277429-3

Straw, Will (1991) "Systems of Articulation, Logics of Change: Communities and Scenes in Popular Music". Cultural Studies 5:3, 368-388. https://doi.org/10.1080/09502389100490311

Straw, Will (2015) "Some things a scene might be: Postface." Cultural Studies 29:3, 476-485. https://doi.org/10.1080/09502386.2014.937947

Tarassi, Silvia (2018) "Multi-Tasking and Making a Living from Music: Investigating Music Careers in the Independent Music Scene of Milan". Cultural Sociology 12:2, 208-223. https://doi.org/10.1177/1749975517733221 
TENK 2019. Tutkimuseettisen neuvottelukunnan ohje 2019: Ihmiseen kohdistuvan tutkimuksen eettiset periaatteet ja ihmistieteiden eettinen ennakkoarviointi Suomessa. Tutkimuseettinen neuvottelukunta. https://tenk.fi/sites/default/files/2021-01/Ihmistieteiden_eettisen_ ennakkoarvioinnin_ohje_2020.pdf (luettu 2.5.2021)

Threadgold, Steven (2015) "(Sub)Cultural Capital, DIY Careers and Transferability: Towards Maintaining 'Reproduction' when using Bourdieu in Youth Culture Research". Youth Cultures and Subcultures: Australian Perspectives. Toim. Sarah Baker \& Brady Robards, Brady \& Bob Buttigieg. Australia: Ashgate. https://doi.org/10.4324/9781315545998-6

Threadgold, Steven (2018) "Creativity, Precarity and Illusio: DIY Cultures and 'Choosing Poverty"'. Cultural Sociology 12:2, 156-173. https://doi.org/10.1177/1749975517722475

Thornberg, Robert (2012) "Informed Grounded Theory". Scandinavian fournal of Educational Research 56:3, 243-259. https://doi.org/10.1080/00313831.2011.581686

Thornton, Sarah (1995) Club Cultures: Music, Media and Subcultural Capital. Cambridge: Polity Press.

Westinen, Elina (2014) The discursive construction of authenticity: resources, scales and polycentricity in Finnish hip hop culture. Jyväskylän yliopisto. Väitöskirja.

Williams, J. Patrick (2011) Subcultural Theory: Traditions and Concepts. IsoBritannia: Polity Press.

Willis, Paul (1977) Learning to Labour: How Working Class Kids Get Working Class fobs. Farnborough: Saxon House.

Woodman, Dan \& Bennett, Andy (2015) "Cultures, Transitions, and Generations: The Case for a New Youth Studies". Youth Cultures, Transitions, and Generations: Bridging the Gap in Youth Research. Toim. Dan Woodman \& Andy Bennett. New York: Palgrave MacMillan. https://doi.org/10.1057/9781137377234 Vuori, Lea (1971) ”Nuorten sakkikäyttäytyminen”. Nuoret tänään:Valtakunnallisen nuorisotutkimuksen tuloksia. Toim. Ritva Aalto \& Sirkka Minkkinen. Helsinki: Otava.

Värri, Taina (toim.) (2018) Miksei aina voi olla perjantai - 80-luvun Radio City 96,2. Helsinki: broholmen 13 . 